
Kidney
Blood Pressure
Research .

\title{
Treatment of Hypertension: Favourable Effect of the Twice-Daily Compared to the Once-Daily (Evening) Administration of Perindopril and Losartan
}

\author{
Ipoly Szauder ${ }^{\mathrm{a}}$ Eszter Csajági ${ }^{\mathrm{b}} \quad$ Zsuzsanna Major ${ }^{\mathrm{c}} \quad$ Gabor Pavlik $^{\mathrm{b}}$ \\ Gabriella Ujhelyid
}

${ }^{a}$ Cardiologic Diagnostic Center, Budapest; ${ }^{b}$ Department of Health Sciences and Sport Medicine, University of Physical Education; 'Department of Physical Education and Sport Sciences, College of Nyíregyháza, Nyíregyháza; dDepartment of Pharmaceutics, Semmelweis University, Budapest, Hungary

\section{Key Words}

Treatment of hypertension - Circadian rhythm - Non-dipper phenomenon - Losartan • Perindopril

\begin{abstract}
Background/Aims: Little is known about the effect of twice daily administration of same dose of ACE inhibitor and ARB on the diurnal/nocturnal blood pressure (BP) ratio. We aimed to assess the effect of two widely used long-acting drugs: perindopril and losartan in the treatment of hypertension comparing the once-daily (evening) vs. twice-daily (morning and evening) administration with the same daily doses. Methods: Untreated primary hypertensive patients without complaints (a total of 164: 65 men, 99 women, $55.7 \pm 13.7$ years of age, 41-41 patients per treated groups) were selected with non-dipper phenomenon, estimated by diurnal index (DI) $<10 \%$. The effect of evening (8 mg perindopril or $100 \mathrm{mg}$ losartan) vs morning and evening (4-4 mg perindopril or 50-50 mg losartan) administration was determined on a 14day treatment by ABPM. Results: The mean $\mathrm{BP}$, the percent time elevation index, and the hyperbaric impact decreased in both drug groups. Significant difference was observed in the DI in the case of twice-daily administration vs once-daily evening dosing. Conclusions: The twice-daily administration with the same daily dose of perindopril or losartan seems to be more effective compared to the once daily evening administration in eliminating the nondipper phenomenon. According to some authors the non-dipping phenomenon increases cardiovascular risk, while others are of the opinion that the association of non-dipping with cardiovascular events does not necessarily mean that selective treatment of non-dipping improves cardiovascular outcomes.
\end{abstract}




\section{Kidney \\ Blood Pressure Research}

Kidney Blood Press Res 2015;40:374-385

DOI: 10.1159/000368513

Published online: July 07, 2015

(c) 2015 S. Karger AG, Basel

www.karger.com/kbr

Szauder/Csajági/Major/Pavlik/Ujhelyi: Effect of the Twice-Daily Administration of Perindopril and Losartan

\section{Introduction}

The most effective, individually tailored treatment of hypertension and the prevention of cardiovascular diseases and their complications can be achieved by the chronobiological approach, knowing the circadian rhythm. The drug's pharmacokinetic effects and side effects may be modified by the circadian rhythm and the time of drug administration [1-4]. In the last two decades the data of 24-hour ambulatory blood pressure monitoring (ABPM) demonstrated that acute cardiovascular events (myocardial infarction, angina pectoris, cardiac arrest, sudden death, pulmonary embolism) in hypertensive patients are closely related to the circadian rhythm [5-9]. Diurnal rhythm is also known in the daily fluctuation of heart rate and blood pressure, i.e. higher diurnal, less nocturnal values. Based on 24-hour BP monitoring, subjects can be classified as non-dippers (nocturnal reduction of systolic pressure by $<10 \%$ of awake systolic pressure), dippers (reduction by $\geq 10 \%$ to $<20 \%$ ), and extreme dippers (reduction by $\geq 20 \%$ ). In some patients so-called "reverse dipping" has been described with an increase in BP during night times [1, 2, 10-13]. The dipper/ non-dipper classification of nocturnal blood pressure was firstly introduced in 1988 when a retrospective analysis suggested that hypertensive patients without nocturnal fall in $\mathrm{BP}$ had a higher risk of stroke than the majority of patients with a dipping pattern $[1,2,14]$. In non-dipper hypertension the number of cardiac events is three times more compared to the dipper type $[5,12,13,15-17]$. In asymptomatic hypertensive patients who underwent 24-hour monitoring and brain magnetic resonance imaging, the frequency of asymptomatic cerebrovascular damage (silent infarcts and advanced deep white matter ischemic lesions) was higher in non-dippers as compared to dippers, and extreme dippers had more advanced cerebrovascular lesions [18].

Several clinical studies assessed the evening and morning administration of benazepril, enalapril, perindopril, quinapril, ramipril and trandolapril, confirming that if these drugs were taken in the evening, they acted more expressly on the nocturnal blood pressure, decreasing the non-dipping phenomenon. It was established that they more effectively decrease the diurnal blood pressure when administered in the morning and they more effectively decrease the nocturnal blood pressure when administered in the evening. Evening administered perindopril did not result in optimum BP control throughout 24 hours, whilst morning administration resulted in an elevated early morning peak during the critical early morning period. It was demonstrated by 24 -hour blood pressure monitoring that significant blood pressure decrease occurred among non-dippers, especially in the nocturnal sleep period, and evening administration decreased the early morning rise to a greater extent compared to morning dosing. It can be explained by the fact that as a result of ACE inhibitor the diurnal/nocturnal blood pressure ratio is similar to the normal biorhythm, favourably influencing the circadian rhythm [19-25]. Similar observations were described in case of the evening administration of ARBs (valsartan, irbesartan, telmisartan, olmesartan) as well. Considering the circadian rhythm-dose connection, with the administration of valsartan the dipper status can be significantly improved and thus the cardiovascular risk can be decreased [25-29]. In these studies one group received the drug in the morning, the other in the evening.

Based on the above facts we can state that morning or evening administered ACE inhibitor or ARB did not result in optimum BP control throughout 24 hours. However, little is known about the effect of the twice daily administration of same doses of ACE inhibitor and ARB on the diurnal/nocturnal blood pressure ratio. This is the aim of our research, the findings of which are as follows.

10 subjects were randomly assigned. Blockade of the RAS was evaluated with the inhibition of the pressor effect of exogenous angiotensin I, an ex vivo receptor assay, and the changes in plasma angiotensin II. With $200 \mathrm{mg}$ OD losartan, trough blockade was $54.14 \%$, but with $100 \mathrm{mg}$ BID it increased to $77.8 \%(\mathrm{p}<0.01)$ [30]. There are important data both about the relationship of the salinity of the diet and the effect of losartan with the intrarenal RAS 


\section{Kidney \\ Blood Pressure Research}

Kidney Blood Press Res 2015;40:374-385

\begin{tabular}{l|l}
\hline DOI: $10.1159 / 000368513$ & (c) 2015 S. Karger AG, Basel
\end{tabular}

Published online: July 07, 2015

www.karger.com/kbr

Szauder/Csajági/Major/Pavlik/Ujhelyi: Effect of the Twice-Daily Administration of Perindopril and Losartan

and the plasma thromboxane A2 level and also about the renoprotective effect of losartan. The effect of losartan in the change of intrarenal RAS: with Wistar rats in high-salt diet, Losartan failed to reduce SBP but abolished the increase of proteinuria, renal cortex renin, angiotensinogen, angiotensin II and urinary angiotensinogen when compared with high salt group [31]. There are similar accounts of the renal protective effect: the losartan/thiazide combination therapy attenuated glomerular overload, indicating that this therapy may provide glomerular protection in patients with an elevated GFR without causing prolonged damage to renal function [32]. With low-salt diet administering $50 \mathrm{mg}$ Losartan inhibition of AT1 receptors could lead to activation of AT2 receptors, which maintain skin hyperaemia despite the increased level of vasoconstrictor thromboxane A2 [33].

Twice-daily dosing at 50-100 mg/day gave consistently larger trough responses than once-daily dosing at the same total dose. Peak ( 6 hour) effects were uniformly, but moderately, larger than trough effects, with the trough-to-peak ratio for systolic and diastolic responses $50-95 \%$ and $60-90 \%$, respectively [34]. The effects of losartan, $50 \mathrm{mg}$ twice daily, were not significantly different from those of losartan, $100 \mathrm{mg}$ once daily, but, as expected, the effects were greater than those of losartan, $50 \mathrm{mg}$ once daily $(\mathrm{p}<.0 .05)$ [35-37]. When once and twice daily dosing were compared, the twice daily regimen was slightly superior, but by no more than about 0.5 to $1 \mathrm{mmHg}$ [38-40]. For this reason we aimed to assess the blood pressure alterations after the administration of two long-lasting drugs (ACE inhibitor: perindopril and ARB: losartan) in the same dose: twice-daily administration of divided dose in the morning and evening (4-4 mg perindopril, 50-50 mg losartan), versus once in the evening (8 mg perindopril and $100 \mathrm{mg}$ losartan) administration performing their comparative analysis, especially in case of hypertensive patients with non-dipper phenomenon presenting known cardiovascular risk.

\section{Materials and Methods}

The Semmelweis University Institutional Committee for Research Ethics determined that the proposed protocol and/or other documents adequately address relevant ethical concerns and meet regulatory requirements of such trials (\#143/2013). Our protocol was designed in accordance with the ethical principles of the Declaration of Helsinki and all participants provided their written consent before entering the study.

The patients were randomly allocated to the different groups by G Ujhelyi. Numbers given to the patients were shuffled and randomly picked. The trial was not registered at clinicaltrials.gov due to the lack of local administrative assistance.

Inclusion criteria were:

newly diagnosed primary hypertensive patients - total of 164 subjects, 65 men/99 women, $55.7 \pm 13.7$ (mean \pm SD) years of age (55.6 \pm 13.8 men, $56.2 \pm 13.2$ women). Average BMI: $24 \pm 2$ men, $21 \pm 3$ women were selected, with systolic blood pressure $\geq 160$ and/or diastolic blood pressure $\geq 100 \mathrm{mmHg}$. The positive diagnosis of hypertension was confirmed by ABPM: patients with either the $24 \mathrm{~h}$ mean systolic and diastolic blood pressure (SBP/DBP) above 130/80 mmHg, the diurnal mean above 135/85 mmHg or the nocturnal mean above $120 / 70 \mathrm{mmHg}$ untreated were considered as hypertensive. Moreover, inclusion criteria required all patients to be non-dipper (here defined as $<10 \%$ decline in nocturnal mean compared with the diurnal mean of SBP using all data sampled by ABPM for 24 consecutive hours).

- Caucasian

- having a sedentary occupation

- $\quad$ BMI $<35$

- non-smoker

- not consuming alcohol or drugs

- having no other comorbidity
- not taking any other medicine regularly

- ejection fraction with echocardiography method: left ventricle hypertrophy, valve disorders

- no cardiologic complaints

- normal sleep quality with normal daily activities

- clinically free of any sleep-related disorder 


\section{Kidney \\ Blood Pressure Research}

Kidney Blood Press Res 2015;40:374-385

\begin{tabular}{l|l}
\hline DOI: 10.1159/000368513 & (C) 2015 S. Karger AG, Basel
\end{tabular}

Published online: July 07, 2015

www.karger.com/kbr
Exclusion criteria were:
- cardiopulmonary disease
- metabolic disorder
- endocrine disorders
- inefficient compliance
- drug consumption
- drug side effect
- sleep disorders
- alcohol consumption
- drug consumption
- anabolic steroid consumption

During 24 hours ABPM each participant wore an „Aktigraf” (motion-logger actigraph, Meditech Ltd, Budapest, Hungary) on the dominant wrist to monitor physical activity every minute. This compact (about the size of a wrist watch) device functions as an accelerometer. The internal clocks of the actigraph and the ABPM devices were synchronized through their respective interfaces by the same computer. The actigraphy data were used to determine the onset and offset times of diurnal activity and nocturnal sleep so as to accurately determine the diurnal and nocturnal BP means of each subject. The mean activity for the 5 minutes before each BP reading was then calculated for further statistical analysis [41].

24-hour ambulatory blood pressure monitoring was performed with "ABPM-05" device (Meditech Ltd, Budapest, Hungary). Measuring methods were: oscillometric method, staged pressure lowering, semiconductor pressure sensor. Measuring range: $30-260 \mathrm{mmHg}$, heart rate 40-200/min. Passive accuracy: $\pm 3 \mathrm{mmHg}$ or $2 \%$ of the measuring value. Data transfer with USB optical cable. The software of the device enables all-round data analysis: mean blood pressure, percent time elevation index (PTEI), hyperbaric impact, diurnal index (DI). The measuring accuracy of ABPM-05 device algorithm was ensured by British Hypertension Society (BHS) and by Association for the Advancement of Medical Instrumentation (AAMI) validations.

The 24-hour ambulatory blood pressure monitor was programmed for measurements every 20 minutes during the day and every 30 minutes during the night. Day period was considered the period from 6 a.m. to 10 p.m., night period was considered from 10 p.m. to 6 a.m. The patient wrote a detailed log-book about the activities. In case of complaints the patient could initiate blood pressure measurement apart from the programmed ones at any time, or could give a sign when reading the measurement data of the device.

In all three studies we measured:

- Systolic and diastolic mean values ( $\mathrm{mmHg}$ )

- Systolic and diastolic hypertensive time index in \%

Hypertensive Time Index, or percent time elevation index (PTEI) is the proportion of time during which blood pressure values are higher than what is considered to be normal. The hypertension time index compares the period with elevated blood pressure to total time. Value above $15 \%$ refers to hypertension, value above $40 \%$ may refer to target organ lesion $[1,2,14]$.

- Systolic and diastolic diurnal index in \% (DI)

Diurnal or day / night index is the difference between day-time and night-time blood pressure expressed in percent (daytime value averages divided by the night-time average and multiplied by 100). $<10 \%$ systolic or diastolic value refers to non-dipper phenomenon, and it may indicate target organ damage, diabetes or non-efficient antihypertensive drug treatment as well. $>20 \%$ diurnal index refers to extreme dipping $[1,2,14]$.

- Systolic and diastolic hyperbaric impact or pressure load: in mmHg x h

Hyperbaric impact or hypertension load provides information on how long blood pressure is higher than normal and how much it is higher than the upper limit of normal ambulatory blood pressure during ABPM monitoring. It expresses the over ranged blood pressure not only in time, but its extent in $\mathrm{mmHg} x$ hour unit. It expresses most accurately the extent of hypertension for the examined period $[1,2,14]$. 


\section{Kidney \\ Blood Pressure Research}

\section{Kidney Blood Press Res 2015;40:374-385}

DOI: 10.1159/000368513

Published online: July 07, 2015

(C) 2015 S. Karger AG, Basel

www.karger.com/kbr

The patients were informed about the purpose of the study and they all agreed with the involvement and completion of the study in each case. To improve the compliance of the patients the morning and the evening times of the drug administration were adjusted ( 8 a.m. and 8 p.m.) on their cell phones and warning messages were sent daily to which the patients forwarded a confirmative feedback if the drug application was performed successfully.

Treatment design:

Study I: drug-free, basic 24-hour blood pressure monitoring (ABPM)

164 patients 65 men, 99 women

Study II: group 1: $8 \mathrm{mg}$ perindopril at 8 p.m.

41 patients (16 men, 25 women)

group 2: $100 \mathrm{mg}$ losartan at 8 p.m.

41 patients (16 men, 25 women)

ABPM after 14 days from first administration

Study III: $\quad$ group 1: $4 \mathrm{mg}$ perindopril at 8 a.m., $4 \mathrm{mg}$ perindopril at $8 \mathrm{p} . \mathrm{m}$.

41 patients ( 16 men, 24 women)

group 2: $50 \mathrm{mg}$ losartan at 8 a.m., $50 \mathrm{mg}$ losartan at 8 p.m.

41 patients (17 men, 25 women)

ABPM after 14 days from first administration

(group 1: treatment with perindopril, group 2: treatment with losartan)

In the first week of the study the patients conducted home blood pressure monitoring three times a day (recumbent after waking up, between 11-12 a.m., between 7-8 p.m.) If their blood pressure did not decrease below 160/100 Hgmm after the first week, as co-medication females got $5 \mathrm{mg}$ of amlodipine. These patients were excluded from further study.

\section{Statistical analysis}

For statistical evaluation R 2.11.1 software package (2010) was applied. Differences between means were evaluated by one-way analysis of variance (one-way ANOVA) with post-hoc Tukey test, if data were of normal distribution and homogeneity of variances was confirmed or Kruskal-Wallis nonparametric test. A p value of $<0.05$ was accepted to indicate statistical significance.

\section{Results}

There was no significant difference except for the diurnal index in the effect of oncedaily (evening) vs twice-daily perindopril and losartan administration (Table 1).

The 24-hour mean systolic values became significantly lower in both the once-daily and the twice-daily administration groups while the diastolic values decreased moderately but not significantly (Figure 1).

Diurnal main systolic values became significantly lower in both the once-daily and the twice-daily administered perindopril and losartan groups while the diastolic values decreased moderately but not significantly.

Night time mean systolic values became significantly lower in both the once daily and the twice daily administered perindopril and losartan groups while the diastolic values decreased moderately but not significantly.

Diurnal blood pressure control was not optimal in either drug groups regardless of dosage. However with once-daily administration the night time mean values were higher while they decreased with twice-daily dosage. This can explain the more favourable diurnal index in the case of the twice daily dosage.

The percent time elevation index (PTEI) and the hyperbaric impact notably decreased, but not significantly in both drug groups in case of evening and twice-daily administration (Figure 2 and 3). 


\section{Kidney \\ Blood Pressure Research}

Kidney Blood Press Res 2015;40:374-385

DOI: 10.1159/000368513

Published online: July 07, 2015

(C) 2015 S. Karger AG, Basel

www.karger.com/kbr

Szauder/Csajági/Major/Pavlik/Ujhelyi: Effect of the Twice-Daily Administration of Perindopril and Losartan

Table 1. Study results

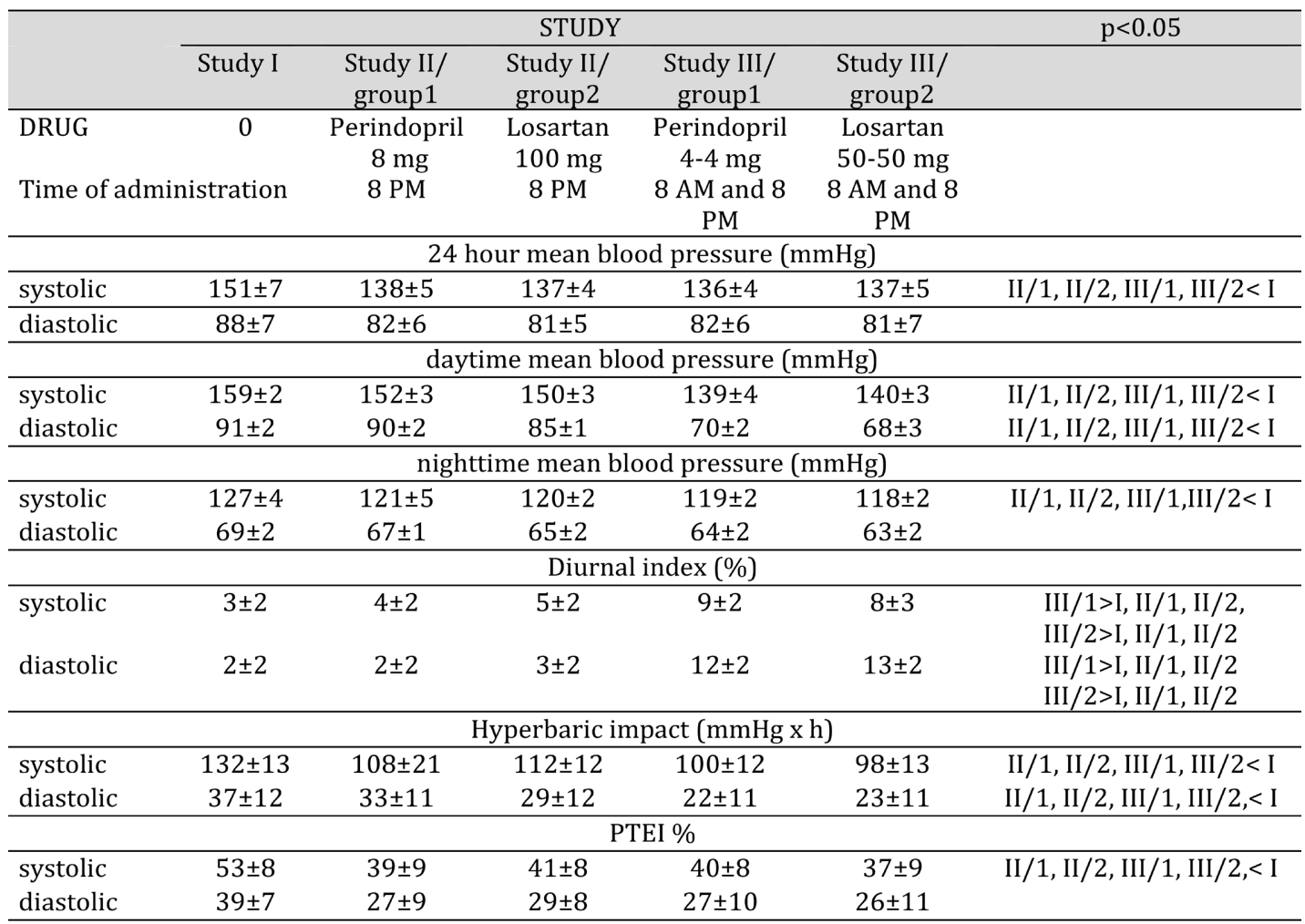

Fig. 1. Mean systolic and diastolic values are expressed in $\mathrm{mmHg}$ in control and in losartan or perindopril-treated groups. No significant differences were found between groups treated once daily or twice daily with perindopril (group 1) and losartan (group 2) ( $>0.05, n=41)$.

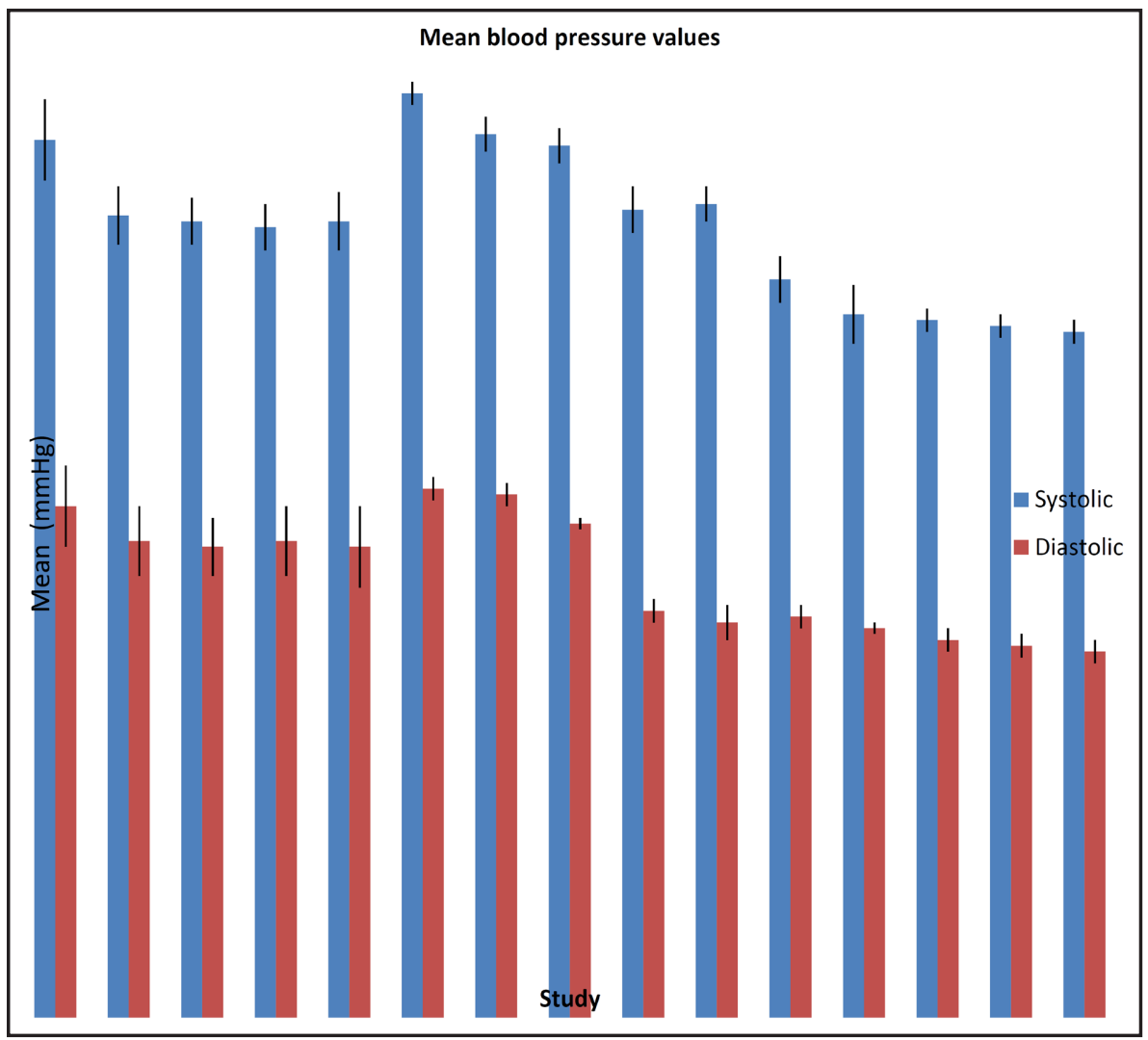




\section{Kidney Blood Pressure Research}

Fig. 2. Systolic and diastolic hypertension time index (PTEI) values in control and in losartan or perindopril-treated groups are described. No significant differences were found between groups treated once daily or twice daily with perindopril (group 1) and losartan (group 2) $(p>0.05, n=41)$.

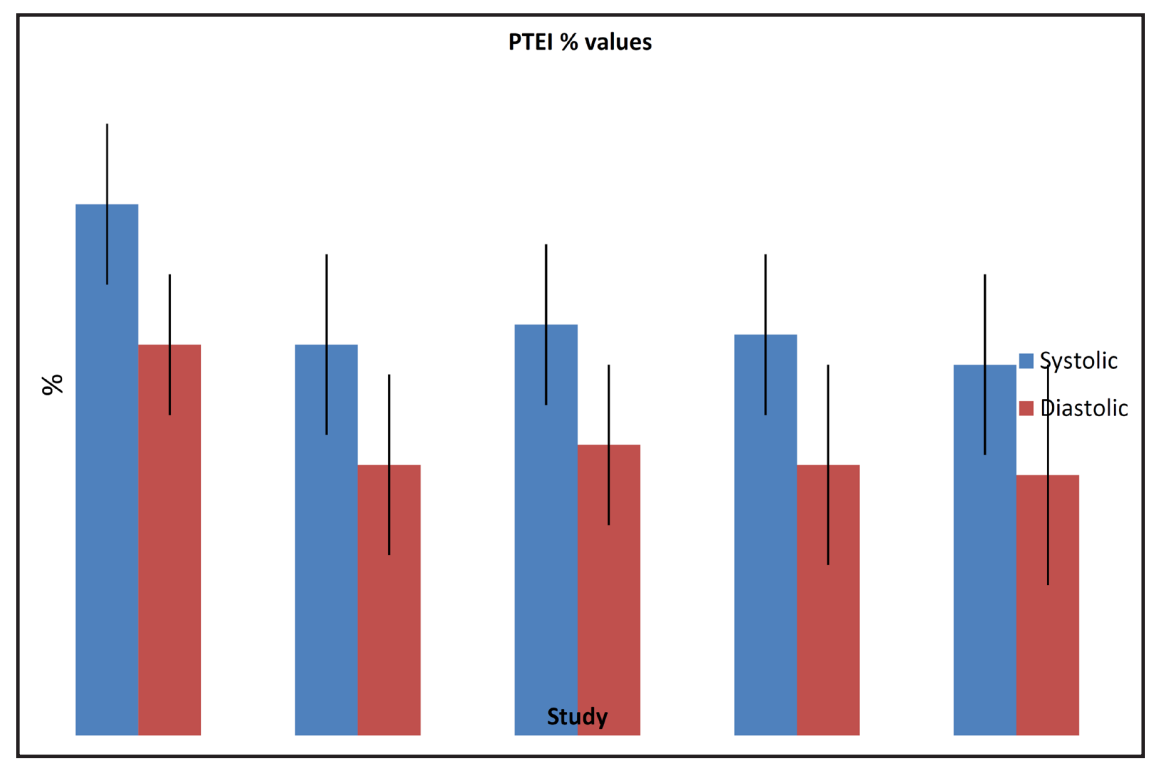

Fig. 3. Hyperbaric impact values are expressed in $\mathrm{mmHg} x \mathrm{~h}$. No significant differences were found between groups treated once daily or twice daily with perindopril (group 1) and losartan (group 2) ( $>0.05, n=41)$.

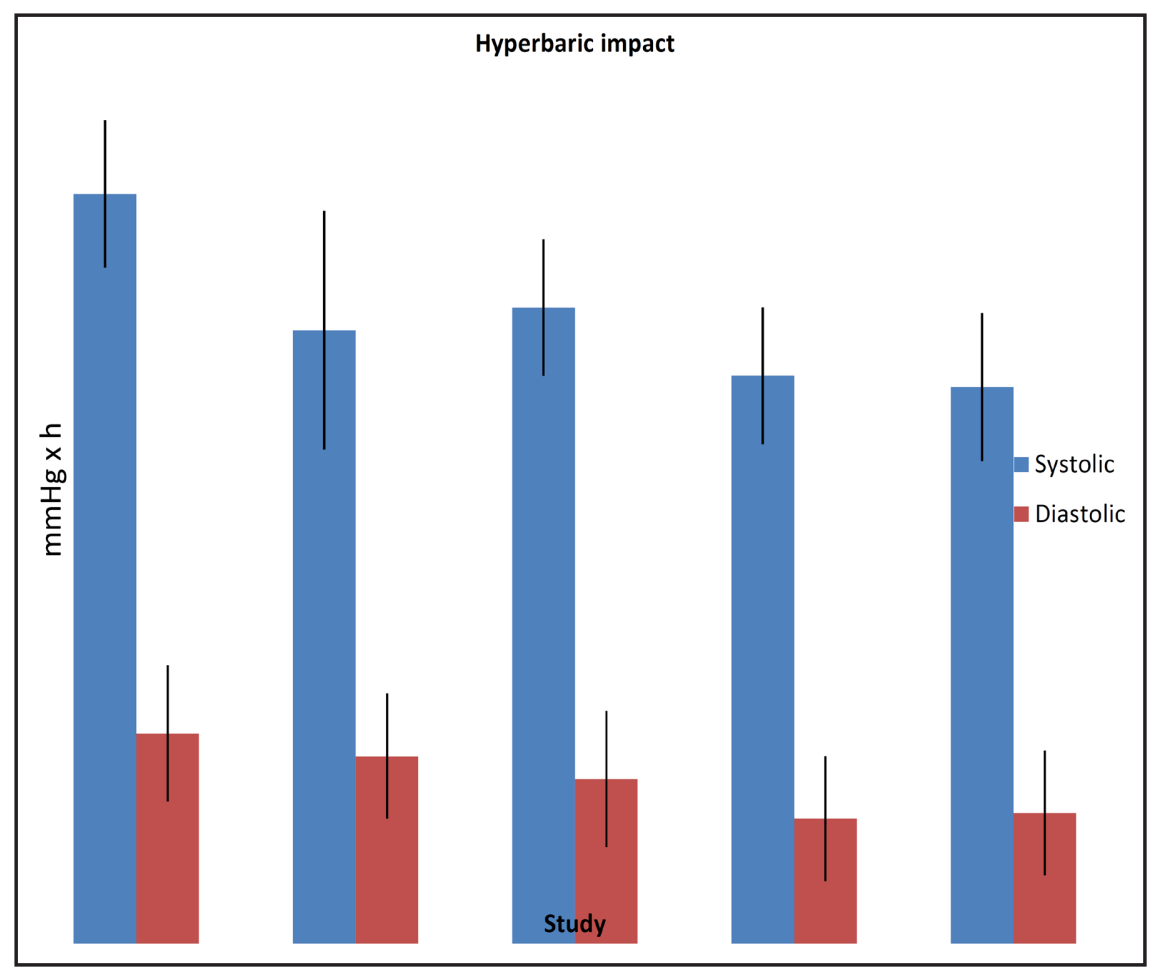

Diurnal index increased non-significantly in case of once-daily administration with both drugs, however, it showed significant $(\mathrm{p}<0.05)$ increase during twice-daily administration both with of losartan and perindopril. $10 \%$ or above of diurnal index indicated the cessation of non-dipper phenomenon (Figure 4).

Comparing the effect of perindopril and losartan: there was no significant difference either in the once-daily or in twice-daily administration group, both drugs moderated the mean blood pressure, PTEI and hyperbaric impact in a similar rate. 


\section{Kidney

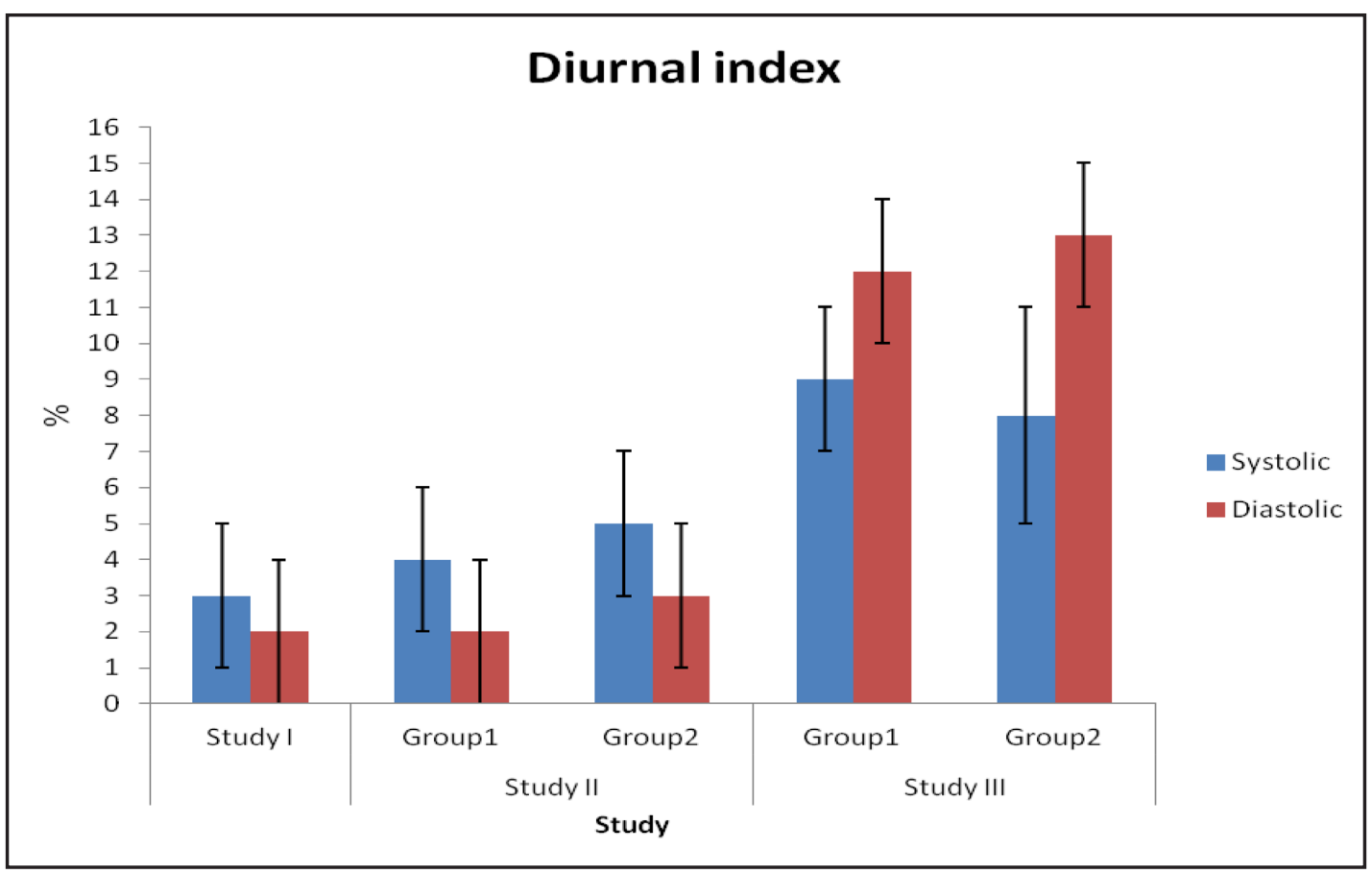

Fig. 4. Diurnal index values are expressed in $\%$. There were significant differences between groups treated once daily or twice daily with perindopril (group 1) and losartan (group 2) $\left(^{*} p<0.05, n=41\right.$ ).

\section{Discussion}

The therapeutic range and efficiency of various antihypertensive drugs significantly depends on their circadian rhythm administration. In hypertension, knowing the frequency of abnormal rise of blood pressure in the morning and night-time, chronotherapy should be applied to reduce the morning rise to a normal level, but also to ensure a favourably influence on the night-time non-dipping period.

Chronotherapy, considering the patients' circadian blood pressure profile, gives scope for the individualized treatment of hypertension, the attainment of optimal blood pressure control and it decreases the risk of cardiovascular diseases and organ lesions. It is known that the evening administration of ACE inhibitors and ARBs resulted in improved diurnal/nocturnal blood pressure ratio (increase of diurnal index), as opposed to morning administration.

Clinical studies have documented that evening administration of ACE inhibitors and ARBs resulted in improved diurnal/nocturnal blood pressure ratio, as opposed to morning administration, however, less is known about the effect of the twice daily administration of the same doses of ACE and ARB on the diurnal/nocturnal blood pressure ratio. The effect of the two most widely used long-acting antihypertensive ACE inhibitor and ARB drugs: perindopril and losartan in the treatment of hypertension comparing the once-daily administration (evening) to the twice-daily (morning and evening) administration in the same dose with 24-hour blood pressure monitoring (ABPM) has been investigated by us.

The once-daily (evening) dose of perindopril $(8 \mathrm{mg}$ ) and losartan $(100 \mathrm{mg})$ and the twice daily administration (morning and evening 4-4 mg perindopril and 50-50 mg losartan) did not significantly decrease the mean blood pressure, the PTEI and the hyperbaric impact.

In twice-daily administration the difference between diurnal and nocturnal blood pressure value, expressed in the percent of daytime value (diurnal index), significantly increased compared to the once-daily evening administration. Based on the study, in 


\section{Kidney \\ Blood Pressure Research}

Kidney Blood Press Res 2015;40:374-385

\begin{tabular}{l|l}
\hline DOI: $10.1159 / 000368513$ & (c) 2015 S. Karger AG, Basel
\end{tabular}

Published online: July 07, 2015

www.karger.com/kbr

Szauder/Csajági/Major/Pavlik/Ujhelyi: Effect of the Twice-Daily Administration of Perindopril and Losartan

the treatment of non-dipper hypertension the twice-daily administration of same dose of perindopril and the same dose of losartan seems to be more favourable to cease nondipper phenomenon than the once-daily evening administration. There is no common understanding regarding cardiovascular events and cardiovascular risks accompanying the non-dipper phenomenon. According to some authors non-dipping increases cardiovascular risk $[5,12,13,15-17,42-46]$ while others are of the opinion that the association of nondipping with cardiovascular events does not necessarily mean that selective treatment of non-dipping improves cardiovascular outcomes. This is explained by the fact that factors other than the non-dipping phenomenon have stronger influence on cardiovascular risk. These factors include age, smoking, inactive way of life, comorbidities like obesity, diabetes mellitus, lipid metabolic disorder [47-54].

Although we did not observe extreme dipping phenomenon i.e. aggressive blood pressure lowering during night time in the course of our study, it is important to mention that aggressive blood pressure lowering during night time in itself can be the risk factor of cardiovascular diseases like ischaemic stroke or nephropathy and it causes nocturnal ischaemia more often than the non-dipper phenomenon. The risk for the primary end points - death and MI, but not stroke - progressively increased with low diastolic blood pressure. Excessive reduction in diastolic pressure should be avoided in patients with CAD who are being treated for hypertension.

While average night time to daytime BP ratio $<0.80$ has been defined as "extreme dipping," and in at least a couple of studies it has been associated with an increased risk of cerebrovascular disease in older adults, a large meta-analysis examining the prognostic significance of night time BP patterns found no difference between dippers and extreme dippers in the rate of cardiovascular events. Among treated hypertensive patients with CAD, nocturnal ischemia was shown to be significantly more frequent in over-dippers than in dippers and non-dippers [55-66].

\section{Conclusion}

The study confirmed the previously known fact that ACE inhibitors or ARBs (in the present study: perindopril and losartan) are not sufficient alone in monotherapy to ensure the appropriate target value (normotension).

\section{Limitations}

The dipping/non-dipping pattern is usually defined on the basis of a single ABPM; this classification, however, may not reflect a true clinical trait. Indeed, a large amount of evidence indicates that classification of dippers and non-dippers has a limited reproducibility. This is mostly due to the fact that sleep quality and depth during night-time can markedly vary from one recording session to another [3,27].

\section{Disclosure Statement}

The authors report no conflicts of interest.

\section{Acknowledgements}

The authors alone are responsible for the content and writing of the article. This research received no specific grant from any funding agency in the public, commercial, or not-for-profit sectors. 


\section{Kidney \\ Blood Pressure Research}

Kidney Blood Press Res 2015;40:374-385

\begin{tabular}{l|l}
\hline DOI: $10.1159 / 000368513$ & (C) 2015 S. Karger AG, Basel
\end{tabular}

Published online: July 07, 2015

www.karger.com/kbr

\section{References}

1 Farsang C, Alföldi S, Kiss I: A hypertonia és a cardiovascularis prevenció kézikönyve. Budapest, Medintel, 2013, pp 76-86.

2 O’Brien E, Parati G, Stergiou G, Asmar R, Beilin L, Bilo G, Clement D, de la Sierra A, de Leeuw P, Dolan E, Fagard R, Graves J, Head GA, Imai Y, Kario K, Lurbe E, Mallion JM, Mancia G, Mengden T, Myers M, Ogedegbe G, Ohkubo T, Omboni S, Palatini P, Redon J, Ruilope LM, Shennan A, Staessen JA, van Montfrans G, Verdecchia P, Waeber B, Wang J, Zanchetti A, Zhang Y: European Society of Hypertension Working Group on Blood Pressure Monitoring: European Society of Hypertension position paper on ambulatory blood pressure monitoring. J Hypertens 2013;31:1731-1768.

3 Xu T, Zhang Y-Q, Tan X-R: The Dilemma of Nocturnal Blood Pressure. J Clin Hypertens (Greenwich) 2012;14:787-791.

4 Smolensky MH: Aspects of human chronopathology, in: Reinberg A, Smolensky MH (Eds): Biological Rhytms and Medicine. Heidelberg, Springer Verlag, 1983, pp 131-209.

5 Lemmer B: The importance of circadian rhytms on drug response in hypertension and coronary heart disease - from mice and man. Pharmacol Ther 2006;111:629-651.

6 Hermida RC, Ayala DE, Calvo C, Portaluppi F, Smolensky MH: Chronotherapy of hypertension: Administration-time dependent effects of treatment on the circadian pattern of blood pressure. Adv Drug Deliv Rev 2007;59:923-939.

7 Lemmer B: The importance of biological rhythms in drug treatment of hypertension and sex-dependent modifications. Chronophysiol Ther 2012;2:9-18.

8 Koppisetti VD, Chandra N, Raju MB: Vital role of chronopharmacology and chronopharmacotherapy in human life. Int J Res Pharm Biomed Sci 2010;1:36-40.

9 Maurya KK, Semwal BC, Singh N, Vivek S, Khatoon R: Chronopharmacology: a tool for therapy of diseases. Int Res J Pharm 2012;3:128-132.

10 Ohdo S: Chronotherapeutic strategy: Rhythm monitoring, manipulation and disruption. Adv Drug Deliv Rev 2010;62:859-875.

11 Baumgart P: Circadian rhythm of blood pressure: internal and external triggers. Chronobiol Int 1991;8:444-450.

12 Deedwania PC: Circadian Rhytms of Cardiovascular Disorders, Armonk. New York, Futura Publishing, 1997, pp 6-28.

13 Cohen MC, Rohtle KM, Lavery CE, Muller JE, Mittleman MA: Meta analysis of the morning excess of acute myocardial infarctus and sudden cardiac death. Am J Cardiol 1997;79:1512-1516.

14 O’Brien E, Sheridan J, O'Malley K: Dippers and non-dippers. Lancet 1988;332:397-399.

15 Portaluppi F, Lemmer B: Chronobiology and chronotherapy of ischemic heart disease. Adv Drug Rev 2007;59:952-965.

16 Willich S, Levy D, Rocco MB, Tofler GH, Stone PH, Muller JE: Circadian variation in the incidence of sudden cardiac death in the Framingham Heart Study population. Am J Cardiol 1987;60:801-806.

17 Fox K, Mulcahy D, Keegan J, Wright C: Circadian patterns of myocardial ischemia. Am Heart J 1989;118:1084-1087.

18 Gaciong Z, Siński M, Lewandowski J: Blood Pressure Control and Primary Prevention of Stroke: Summary of the Recent Clinical Trial Data and Meta-Analyses. Curr Hypertens Rep 2013;15:559-574.

19 Yusuf S, Sleight P, Pogue J, Bosch J, Davies R, Dagenais G: The Heart Outcomes Prevention Evaluation Study Investigators. Effects of an angiotensin-converting enzyme inhibitor: ramipril on cardiovascular events in high risk patients. N Eng J Med 2000;342:145-153.

20 Witte K, Weisser K, Neubeck M, Mutschler E, Lehmann K, Hopf R, Lemmer B: Cardiovascular effects, pharmacokinetics and converting enzyme inhibition of enalapril after morning versus evening administration. Clin Pharmacol Ther 1993;54:177-186.

21 Palatini P: Can an angiotensin-converting enzyme inhibitor with a short half-life effectively lower blood pressure for 24 hour. Am Heart J 1992;123:1421-1425.

22 Kuroda T, Kario K, Hoshide S, Hashimoto T, Nomura Y, Saito Y, Mito H, Shimada K: Effects of evening vs. morning administration of the long acting lipophylic angiotensin-converting enzyme inhibitor trandolapril on morning blood pressure in hypertensive patients. Hypertens Res 2004;27:2715-2720. 


\section{Kidney \\ Blood Pressure Research}

Kidney Blood Press Res 2015;40:374-385

\begin{tabular}{l|l}
\hline DOI: $10.1159 / 000368513$ & (C) 2015 S. Karger AG, Basel
\end{tabular}

Published online: July 07, 2015

www.karger.com/kbr

23 Morgan T, Anderson A, Jones E: The effect on 24 hour blood pressure control of an ACE inhibitor (perindopril) given in the morning or at night. J Hypertens 1997;15:205-211.

24 Hermida RC, Calvo C, Ayala DE, Chayán L, Rodríguez M, López JE: Chronotherapy with spirapril in hypertensive patients: changes in the diurnal/nocturnal blood pressure ratio as a function of the circadian time of administration. J Hypertens 2006;24:S88.

25 Pizzuto M, Portelli J, Serracino-Iglott A, Zarb-Adami M, Azzopardi L: Chronopharmacology of antihypertensives. J Appl Res 2010;7:133-140.

26 Hermida RC, Calvo C, Ayala DE, Domínguez MJ, Covelo M, Fernández JR, Mojón A, Lóp JE: Administration time-dependent effects of valsartan on ambulatory blood pressure in hypertensive subjects. Hypertension 2003;23:283-290.

27 Hermida RC, Calvo C, Ayala DE, Fernández JR, Covelo M, Mojón A, López JE: Treatment of non-dipper hypertension with evening administration of valsartan. J Hypertens 2005;23:1913-1922.

28 Smolensky MH, Hermida RC, Portaluppi F: Comparison of the efficacy of morning versus evening administration of olmesartan in uncomplicated essential hypertension. Chronobiol Int 2007;24:171-181

29 Fukuda M, Yamanake T, Mizuno M, Motokawa M, Shirasawa Y, Miyagi S, Nishio, T, Yoshida A, Kimura G: Angiotensin II type 1 receptor blocker olmesartan, restores nocturnal blood pressure decline by enhancing daytime natriuresis. J Hypertens 2008;26:583-588.

30 Forclaz A, Maillard M, Nussberger J, Brunner HR, Burnier M: Angiotensin II Receptor Blockade Is There Truly a Benefit of Adding an ACE Inhibitor? Hypertension 2003;41:31-36.

31 Wu H, Liang Y, Zheng Y, Bai Q, Zhuang ZAL, Zheng D, Wang Y: Up-regulation of intrarenal renin-agiotensin system contributes to renal damage in high-salt induced hypertension rats. Kidney Blood Press Res 2014;39:526-535.

32 Hasegawa H, Tayama Y, Takayanagi K, Asakura J, Nakamura T, Kawashima K, Shimizu T, Iwashita T, Ogawa T, Matsuda A, Mitarai T: Release from glomerular overload by the addition of low-dose thiazide in patients with angiotensin receptor blocker-resistant hypertension. Kidney Blood Press Res 2013;37:521-530.

33 Cavka A, Cosic A, Grizelj I, Koller A, Jelaković B, Lombard JH, Phillips SA, Drenjancevic I: Effects of AT1 receptor blockade on plasma thromboxane A2 (TXA2) level and skin microcirculation in young healthy women on low salt diet. Kidney Blood Press Res 2013;37:432-442.

34 Sica DA, Gehr TWB, Ghosh S: Clinical pharmacokinetics of Losartan. Clin Pharmacokinet 2005;44:797-814.

35 Dina R, Jafari M: Angiotensin II-Receptor Antagonists: An Overview. Am J Health Syst Pharm 2000;57:12311241.

36 Weber MA, Byyny RL, Pratt JH, Faison EP, Snavely DB, Goldberg AI, Nelson EB: Blood pressure effects of the angiotensin II receptor blocker, losartan. Arch Intern Med 1995;155: 405-411.

37 Mancia G: Angiotensin II Receptor Antagonists. London, Martin Dunitz, 2000 p. 49.

38 Zanchetti A: First-Line Treatment in Hypertension. Role of Perindopril. Drugs 1990;39:71-75.

39 Chrysant SG, McDonald RH, Wright JT, Barden PL, Weiss RJ: Perindopril as monotherapy in hypertension: a multicenter comparison of two dosing regimens. The Perindopril Study Group. Clin Pharmacol Ther 1993;53:479-484.

40 Zappe DH, Crikelair N, Kandra A, Palatini P: Time of administration important? Morning versus evening dosing of valsartan. J Hypertens 2015;33:385-392.

41 Mansoor GA: Sleep actigraphy in hypertensive patients with the non-dipper blood pressure. J Hum Hypertens 2002;6:237-242.

42 Ferrara AL, Pasanisi F, Crivaro M, Guida L, Palmieri V, Gaeta I: Cardiovascular abnormalities in nevertreated hypertensives according to nondipper status. Am J Hypertens 1998;11:1352-1357.

43 Björklund K, Lind L, Zethelius B, Berglund L, Lithell H: Prognostic significance of 24-h ambulatory blood pressure characteristics for cardiovascular morbidity in a population of elderly men. J Hypertens 2004;22:1691-1697.

44 Ingelsson E, Björklund-Bodegard K, Lind L, Arnlöv J, Sundström J: Diurnal blood pressure pattern and risk of congestive heart failure. JAMA 2006;295:2859-2866.

45 Cuspidi C, Macca G, Sampieri L, Fusi V, Severgnini B, Michev I, Salerno. M, Magrini F, Zanchetti A: Target organ damage and non-dipping pattern defined by two sessions of ambulatory blood pressure monitoring in recently diagnosed essential hypertensive patients. J Hypertens 2001;19:1539-1545. 


\section{Kidney \\ Blood Pressure Research}

Kidney Blood Press Res 2015;40:374-385

\begin{tabular}{l|l}
\hline DOI: 10.1159/000368513 & (c) 2015 S. Karger AG, Basel
\end{tabular}

Published online: July 07, 2015

www.karger.com/kbr

46 Cuspidi C, Meani S, Salerno M, Valerio C, Fusi V, Severgnini B: Cardiovascular target organ damage in essential hypertensives with or without reproducible nocturnal fall in blood pressure. J Hypertens 2004;22:273-280.

47 Friedman O, Logan AG: Can nocturnal hypertension predict cardiovascular risk? Integr Blood Press Control 2009;2:25-37.

48 Pickering TG, Kario K: Nocturnal non-dipping: what does it augur? Curr Opin Nephrol Hypertens 2001;10:611-616.

49 Brotman DJ, Davidson MB, Boumitri M, Vidt DG: Impaired diurnal blood pressure variation and all-cause mortality. Am J Hypertens 2008;21:92-97.

50 Birkenhager AM, van den Meiracker AH: Causes and consequences of a non-dipping blood pressure profile. Neth J Med 2007:65:127-131.

51 Hermida RC, Ayala DE, Fernandez JR, Calvo C: Chronotherapy improves blood pressure control and reverts the nondipper pattern in patients with resistant hypertension. Hypertension 2008;51:69-76.

52 Boggia J, Li Y, Thijs L, Hansen TW, Kikuya M, Björklund-Bodegard K, Richart T, Richart T, Ohkubo T: Prognostic accuracy of day versus night ambulatory blood pressure: a cohort study. Lancet 2007;370:12191229.

53 Hansen TW, Jeppesen J, Rasmussen S, Ibsen H, Torp-Pedersen C: Ambulatory blood pressure and mortality: a population - based study. Hypertension 2005;45:499-504.

54 Hansen TW, Jeppesen J, Rasmussen S, Ibsen H, Torp-Pedersenc C: Ambulatory blood pressure monitoring and risk of cardiovascular disease: a population based study. Am J Hypertens 2006;19:243-250.

55 Fagard R, Celis H, Thijs L, Staessen JA, Clement DL, De Buyzere ML, De Bacquer DA: Daytime and nighttime blood pressure as predictors of death and cause-specific cardiovascular events in hypertension. Hypertension 2008;51:55-61.

56 Kario K, Pickering TG, Matsuo T, Hoshide S, Schwartz JE, Shimada K: Stroke prognosis and abnormal nocturnal fall in older hypertensives. Hypertension 2001;38:852-857.

57 Fagard R: Dipping pattern of nocturnal blood pressure in patients with hypertension. Exp Rev Cardiovasc Ther 2009;7:599-605.

58 Viera AJ, Lin Feng-Chang, Hinderliter AL, Shimbo D, Person SD, Pletcher MJ, Jacobs DR: Nighttime blood pressure dipping in young adults and coronary artery calcium 10-15 years later. The Cardia Study. Hypertension 2012;59:1157-1163.

59 Stanton AV: The clinical relevance of extreme dipping. Blood Press Monit 1998;3:163-166.

60 Otsuka K, Cornelissen G, Halberg F, Oehlerts G: Excessive circadian amplitude of blood pressure increases risk of ischemic stroke and nephropathy. J Med Eng Technol 1997;21:23-30.

61 Mancia G, Corrao G: Targeting blood pressure in the management of total cardiovascular risk. Eur Heart J 2009;11: F27-F32.

62 Mancia G, Fagard R, Narkiewicz K, Redo J, Zanchetti A, Böhm M), Christiaens T, Cifkova R, De Backer G, Dominiczak A, Galderisi M, Grobbee DE, Jaarsma T, Kirchhof P, Kjeldsen SE, Laurent S, Manolis AJ, Nilsson PM, Ruilope LM, Schmieder RE, Sirnes PA, Sleight P, Viigimaa M, Waeber B, Zannad F, Task Force Members: 2013 ESH/ESC Guidelines for the management of arterial hypertension: theTask Force for the management of arterial hypertension of the European Society of Hypertension (ESH) and of the European Society ofCardiology (ESC). J Hypertension 2013;31:1281-1357.

63 Turnbull F: Effects of different blood-pressure-lowering regimens on major cardiovascular events: results of prospectively-designed overviews of randomised trials. Lancet 2003;362:1527-1535.

64 Schrier RW, Estacio RO, Esler A, Mehler P: Effects of aggressive blood pressure control in normotensive type 2 diabetic patients on albuminuria, retinopathy and strokes. Kidney Int 2002;61:1086-1097.

65 Estacio RO, Jeffers BW, Gifford N, Schrier RW: Effect of blood pressure control on diabetic microvascular complications in patients with hypertension and type 2 diabetes. Diabetes Care 2000;23:B54-B64.

66 Messerli FH, Mancia G, Conti CR, Hewkin AC, Kupfer S, Champion A, Kolloch R, Benetos A, Pepine CJ: Dogma disputed: can aggressively lowering blood pressure in hypertensive patients with coronary artery disease by dangerous? Ann Intern Med 2006;144:884-893. 